\title{
Faktor yang Memengaruhi Kualitas Hidup Pasien Paska Bedah Pintas Arteri Koroner
}

\section{Factors Affecting the Quality of Life of Patients After Coronary Artery Bypass Surgery}

\author{
Widyadari Prasetyaningrum $^{1}$, M. Rizki Akbar ${ }^{2}$, Ayu Prawesti $^{3}$ \\ ${ }^{1,3}$ Fakultas Ilmu Keperawatan, Universitas Padjadjaran Bandung, Indonesia \\ ${ }^{2}$ Fakultas Kedokteran, Universitas Padjadjaran Bandung, Indonesia
}

\section{ARTICLE INFO}

\section{Article history}

Received date

01 Mar 2021

Revised date

05 Apr 2021

Accepted date

06 Apr 2021

\section{Keywords:}

Bypass grafting;

Coronary artery;

Pain;

Quality of Life.

\section{Kata kunci:}

Bedah pintas;

Arteri koroner;

Nyeri;

Kualitas hidup.

\author{
ABSTRACT/ ABSTRAK
}

Coronary Artery Bypass Grafting (CABG) is aimed to improve the quality of life among post-CABG patients, there exist a large number of patients having a low level of quality of life. The study aimed to analyze factors that influenced the quality of life among postCABG patients. The descriptive study was conducted using cross-sectional analysis with a consecutive sampling of 80 post CABG patients in Hasan Sadikin Hospital from 20 May-30 June 2019. Data were analyzed using multivariate linear regression. The independent variables in this study included age, gender, education level, pain, mental health, social support, spiritual well-being, and cardiac rehabilitation. The data were collected using three questionnaires which included Short-Form 36 (SF-36) to measure patient-reported pain, mental health, and the quality of life; Multidimensional Scale of Perceived Social Support (MSPSS) to provide information about the role of social support; and Spirituality Index of Well Being (SIWB) designed to measure the spiritual well-being of the patients. The results showed four factors had significantly influenced the quality of life among patients after CABG. The factors included age (p-value $<0,001$ $\mathrm{r}=0,521$ ), pain level ( $\mathrm{p}$-value $<0,001 ; \mathrm{r}=0,666)$, mental health ( $\mathrm{p}$-value $<0,001 ; \mathrm{r}=0,426$ ), and social support ( $\mathrm{p}$-value $<0,001 ; \mathrm{r}=0,345)$. Pain factor had the most significant effect on the patients $(r=0,497)$. Pain could cause a stress response that influenced the recovery stage which eventually impacted the quality of life. This study implies that the management of post-CABG patients could be performed by applying pain and stress management in discharge planning.

\begin{abstract}
Operasi Bedah Pintas Arteri Koroner (BPAK) bertujuan memperbaiki kualitas hidup tapi masih ditemukan pasien dengan kualitas hidup rendah. Tujuan penelitian menganalisis faktor-faktor yang memengaruhi kualitas hidup pasien pasca BPAK. Penelitian merupakan penelitian deskriptif analitik cross sectional dengan consecutive sampling pada 80 pasien paska BPAK di ruang Rehabilitasi Jantung dan Poli Jantung RSUP Dr. Hasan Sadikin Bandung sejak 20 Mei-30 Juni 2019. Analisis data dengan multivariat regresi linier. Variabel bebas meliputi usia, jenis kelamin, tingkat pendidikan, rasa nyeri, kesehatan mental, dukungan sosial, kesejahteraan spiritual dan rehabilitasi jantung. Rasa nyeri, kesehatan mental dan kualitas hidup diukur menggunakan kuesioner Short-Form 36 (SF-36), dukungan sosial diukur dengan kuesioner Multidimensional Scale of Perceived Social Support (MSPSS) dan kesejahteraan spiritual diukur dengan kuesioner Spirituality Index of Well Being (SIWB). Hasil penelitian didapatkan empat faktor yang memengaruhi kualitas hidup pada pasien paska BPAK yaitu usia ( $p$-value $<0,001$; $\mathrm{r}=0,521$ ), rasa nyeri ( $p$-value $<0,001 ; \mathrm{r}=0,666)$, kesehatan mental ( $p$-value $<0,001$; $\mathrm{r}=0,426)$ dan dukungan sosial ( $p$-value $<0,001 ; \mathrm{r}=0,345$ ). Rasa nyeri merupakan faktor yang paling memengaruhi kualitas hidup pasien paska BPAK $(r=0,497)$. Rasa nyeri dapat mengakibatkan respon stres sehingga memengaruhi kualitas hidup pasien. Manajemen pasien paska BPAK dapat dilakukan dengan manajemen nyeri dan manajemen stres pada discharge planning.
\end{abstract}

Corresponding Author:

Widyadari Prasetyaningrum,

Fakultas Ilmu Keperawatan, Universitas Padjadjaran Bandung, Indonesia

Email: wewith18@gmail.com 


\section{PENDAHULUAN}

Operasi Coronary Artery Bypass Grafting (CABG) atau Bedah Pintas Arteri Koroner (BPAK) meningkat seiring dengan bertambahnya penderita Penyakit Arteri Koroner (PAK). Data World Health Organization (WHO) menunjukkan bahwa dari 57 juta kematian yang terjadi di dunia, sebanyak 36 juta disebabkan oleh Penyakit Tidak Menular (PTM). Proporsi terbesar penyebab kematian PTM pada orangorang berusia kurang dari 70 tahun adalah penyakit kardiovaskuler yaitu sebesar 39\%. Pada tahun 2030 diprediksi akan ada 52 juta jiwa kematian per tahun karena penyakit tidak menular (Pusat Data dan Informasi Kemenkes RI, 2012).

Sebagaimana telah diketahui penatalaksanaan medis pasien dengan PAK secara umum dilakukan dengan revaskularisasi. Revaskularisasi merupakan tindakan membuka sumbatan pada arteri koroner. Tindakannya dapat berupa terapi trombolitik, intervensi koroner perkutan (IKP) dan tindakan operasi bedah pintas arteri koroner (BPAK) (Nuraeni, et al, 2016). Berdasarkan data pada National Health Service (NHS) tahun 2015 di Inggris terdapat sekitar 20.000 kasus operasi BPAK setiap tahunnya. Sebagian besar operasi BPAK tersebut dilakukan pada laki-laki dan sekitar $80 \%$ menangani pasien berusia 60 tahun. Sejalan dengan itu Alexander \& Smith (2016) menyampaikan bahwa BPAK juga menjadi prosedur bedah utama yang paling umum dilakukan di Amerika Serikat, dengan perkiraan 400.000 operasi dilakukan setiap tahunnya.

Tindakan operasi BPAK di provinsi Jawa Barat terbanyak dilakukan di RSUP. Dr. Hasan Sadikin Bandung yaitu sebanyak 52 kasus (pada bulan Januari sampai dengan Juli 2018). Berdasarkan hasil wawancara yang telah peneliti lakukan di RSUP Dr. Hasan Sadikin Bandung, peneliti mendapatkan data bahwa setiap bulan terdapat 12 operasi jantung dengan perkiraan prevalensi $60 \%$ operasi BPAK, $30 \%$ operasi katup dan $10 \%$ operasi jantung kongenital.

Peningkatan jumlah prosedur BPAK ini sebaiknya juga didukung oleh meningkatnya kualitas hidup pasien paska BPAK. Sehingga tujuan dilakukannya prosedur BPAK yaitu meningkatkan kualitas hidup pasien PAK dengan mengurangi angina dan gejala PAK lainnya terlaksana (NHLBI, 2014).

World Health Organization (WHO) mendefinisikan kualitas hidup sebagai persepsi individu tentang keberadaannya dalam kehidupan terkait dengan budaya dan sistem nilai dimana individu tersebut tinggal yang berhubungan dengan tujuan, harapan, standar dan perhatian mereka (Cassar \& Baldacchino, 2012). Kualitas hidup juga diartikan sebagai good life oleh Ventegodt, et al (2003).

Penelitian Taghipour, et al (2011) menjelaskan bahwa BPAK menunjukkan hasil yang lebih tinggi dan memuaskan pada nilai kualitas hidup. Penelitian mendukung lainnya dilakukan Hlatky, et al (2009) yang melaporkan setelah dilakukan tindak lanjut (follow-up) setahun setelah menjalani BPAK, pada pasien paska BPAK lebih sedikit terjadi angina dibandingkan pada pasien dengan tindakan IKP. Hal berbeda ditemukan pada penelitian Middel, et al (2014) yaitu terdapat penurunan kualitas hidup pada tindakan revaskularisasi dengan BPAK ketika dihubungkan dengan kecemasan, depresi dan tipe kepribadian.

Meskipun masih ditemukan penurunan kualitas hidup pasien paska BPAK pada 1 bulan (Khoueiry, et al., 2011) dan 6 bulan setelah operasi (Middel, et al., 2014). Tetapi lebih banyak penelitian mendapatkan adanya peningkatan kualitas hidup pada pasien dengan operasi BPAK yaitu pada 6 bulan dan 12 bulan setelah operasi (Bak \& Marcisz, 2014). Tindakan revaskularisasi BPAK dapat memperkecil kemungkinan terjadinya serangan angina.

Berdasarkan kajian yang telah peneliti lakukan ditemukan bahwa meskipun sudah dilakukan tindakan revaskularisasi BPAK, tidak semua pasien mengalami peningkatan kualitas hidup. Bahkan dalam beberapa penelitian masih ditemukan pasien yang mengalami penurunan kualitas hidup meskipun telah dilakukan tindakan revaskularisasi. Sehinggga berdasarkan fenomena tersebut peneliti ingin lebih fokus melakukan pengamatan terhadap kualitas hidup pasien setelah tindakan revaskularisasi khususnya paska BPAK untuk melihat faktor yang menyebabkan masih ditemukannya kualitas hidup yang rendah pada pasien paska BPAK.

Penelitian yang telah dilakukan sebelumnya menemukan banyak faktor yang dapat memengaruhi kualitas hidup pasien paska BPAK. Seperti pada penelitian Aziza (2010) yang mengukapkan bahwa dukungan keluarga, pengetahuan pasien tentang tindakan BPAK, prosedur dan tindakan yang dilakukan saat BPAK serta kondisi fisik dan psikologis pasien secara umum dapat memengaruhi kualitas hidup pasien paska BPAK.

Dalam beberapa penelitian disampaikan bahwa karakteristik responden ikut memengaruhi kualitas hidup seseorang setelah dilakukan operasi BPAK. Radi, et al (2009) menemukan 
bahwa usia lebih muda mempunyai kualitas hidup yang lebih baik dibandingkan dengan usia lebih tua. Penelitian oleh Nazir, et al (2007) juga mendapatkan bahwa kualitas hidup pasien paska bedah pintas koroner yang menjalani rehabilitasi fase III lebih baik pada kelompok pendidikan yang tinggi (akademi/universitas) dibandingkan dengan pendidikan yang lebih rendah.

Setelah menjalani operasi BPAK, pasien mungkin mengalami masalah fisik dan psikologis seperti rasa sakit, masalah tidur, kebocoran di daerah operasi, keterbatasan gerakan, sembelit, kelelahan, masalah kognitif dan penyesuaian psikologis yang sulit (Direk \& Celik, 2012). Beberapa penelitian menemukan bahwa rasa nyeri setelah tindakan revaskularisasi juga memengaruhi kualitas hidup. Apabila nyeri akut tersebut tidak teratasi dengan tepat maka dapat mengakibatkan terjadinya nyeri yang terusmenerus. Penelitian Bjornnes, et al tahun 2017 mendapatkan bahwa intensitas nyeri yang terusmenerus berhubungan dengan rendahnya kualitas hidup pasien setelah operasi jantung.

Kondisi kesehatan mental pasien juga ikut memengaruhi kualitas hidup paska BPAK. Seperti pada penelitian oleh Khoueiry, et al (2011) yang menemukan peningkatan tingkat depresi, disablitas, dan rendahnya kualitas hidup pasien pada 1 bulan setelah menjalani BPAK. Dukungan sosial juga dapat mengurangi stres fisik dan respon psikologis (depresi dan kecemasan) yang berdampak pada kualitas hidup (Staniute, et al., 2013).

Selain itu, pemulihan setelah operasi jantung juga dipengaruhi akan adanya kesejahteraan spiritual. Kesejahteraan spiritual memiliki pengaruh positif baik pada pemulihan fisik maupun pemulihan psikologis. Pada pemulihan fisik, spiritualitas berhubungan dengan komplikasi yang lebih sedikit, Length of Stay (LOS) yang lebih pendek, meningkatkan fungsi fisik, dan mengurangi mortalitas jangka pendek. Mouch \& Sonnega (2012) mendapatkan pemulihan psikologis dan spiritualitas berhubungan dengan peningkatan optimisme pra operasi dan penurunan depresi serta distres setelah operasi.

Banyak pasien memerlukan prosedur lain paska BPAK karena kondisi fisik seperti perkembangan penyakit yang telah ada pada arteri jantung mengakibatkan terjadinya penyumbatan berikutnya pada pembuluh cangkok. Sehingga setelah kondisi akut pasien teratasi dan status hemodinamik stabil, pasien dianjurkan untuk mengikuti program pemulihan melalui program rehabilitasi jantung.
Department of Cardiothoracic Surgery, National Heart Centre Singapore (2017) menyebutkan masa pemulihan pasien paska BPAK berlangsung hingga 2 bulan. Masa rawat inap tanpa komplikasi dapat berlangsung seminggu dan proses penyembuhan luka operasi antara 6 minggu hingga 2 bulan. Pada rentang waktu tersebut masih perlu dilakukan monitoring terhadap kondisi pasien. Rehabilitasi jantung adalah program multidisiplin yang meliputi perawatan medis, konseling gizi, berhenti merokok, intervensi faktor risiko, manajemen stres, dan terapi olahraga (Mampuya, et al, 2012). Pasien yang menerima program rehabilitasi, kembali bekerja lebih cepat dan menunjukkan tanda-tanda perbaikan dalam kualitas hidup dan fungsi mental. Penelitian Masoumi, et al (2017) mendapatkan bahwa terjadi peningkatan kualitas hidup pada pasien yang menjalani operasi BPAK setelah intervensi rehabilitasi jantung.

Telah disampaikan pada berbagai kajian bahwa prosedur BPAK ini dilakukan oleh tim dari berbagai multidisiplin sehingga pengelolaan pasien paska BPAK juga merupakan kerjasama dari tim. Salah satu anggota tim pengelola pasien paska BPAK adalah perawat. Perawat memegang peranan penting dalam pengelolaan pasien paska BPAK yaitu dengan melakukan pengkajian dalam upaya peningkatan kualitas hidup pasien paska BPAK. Data pengkajian tersebut akan dirumuskan menjadi diagnosa keperawatan dan menentukan intervensi keperawatan sehingga pengingkatan kualitas hidup pada pasien paska BPAK dapat terjadi. Dalam mengkaji perawat juga perlu mengetahui faktor apa saja yang dapat memengaruhi kualitas hidup pasien paska BPAK agar intervensi yang direncanakan dapat dilakukan sesuai dengan kebutuhan dan masalah pasien.

Penelitian terkait Kualitas Hidup Pasien Paska BPAK telah banyak dilakukan seperti pada penelitian yang juga dilakukan Rosidawati, et al (2015) dengan metode kualitatif, namun penelitian yang secara khusus menganalisis tentang faktor yang memengaruhi kualitas hidup pada pasien paska BPAK belum banyak dilakukan. Peningkatan kualitas hidup pasien paska BPAK merupakan tujuan dari penatalaksanaan kesehatan pada pasien PAK yang telah dilakukan operasi, sehingga studi tentang kualitas hidup serta faktor-faktor yang memengaruhinya penting untuk dilakukan.

Tujuan penelitian untuk menganalisis faktor-faktor yang memengaruhi kualitas hidup pasien paska BPAK di RSUP Dr. Hasan Sadikin Bandung. Hasil penelitian dapat memberikan 
data terkait faktor yang memengaruhi kualitas hidup paska BPAK dan memberikan manfaat bagi perawat dalam memberikan asuhan keperawatan sehingga dapat meningkatkan kualitas hidup pasien.

\section{METODE}

Penelitian ini merupakan penelitian deskriptif analitik dengan pendekatan cross sectional. Populasi target yaitu seluruh pasien paska BPAK dan populasi terjangkau dalam penelitian ini adalah seluruh pasien paska BPAK yang melakukan operasi di RSUP Dr. Hasan Sadikin Bandung. Pengambilan sampel dalam penelitian ini menggunakan teknik nonprobability sampling yaitu consecutive sampling. Kriteria inklusi sampel pada penelitian ini yaitu:

1) Pasien yang telah menjalani operasi BPAK $\geq 1$ bulan sampai dengan 2 tahun.

2) Keadaan umum baik dan kesadaran composmentis.

3) Mampu berkomunikasi dengan baik dan kooperatif.

4) Bersedia menjadi responden ditunjukkan dengan bersedia menandatangani informed concent.

Sedangkan kriteria eksklusi sampel dalam penelitian ini adalah pasien dengan komplikasi penyakit gagal jantung dan pasien yang mengalami gangguan fungsi kognitif.

Penentuan besar sampel menurut Dahlan (2010) dapat menggunakan rumus $\mathrm{n}=\mathrm{f}\left(\alpha, \beta, \mathrm{VB}, \mathrm{R}^{2}\right)$. Dengan melihat tabel Besar Sampel untuk Analisis Regresi Linier dengan $\alpha=5 \%, \quad \beta=20 \%$, maka besar sampel yang diperlukan adalah sebesar 69 responden. Proses penelitian ini dilakukan sejak bulan Februari 2018 hingga Agustus 2019. Adapun proses pengumpulan data dilakukan selama 1 bulan dimulai sejak 20 Mei sampai dengan 30 Juni 2019 di Ruang Rehabilitasi Jantung dan Poli Jantung RSUP Dr. Hasan Sadikin Bandung. Selain itu peneliti juga mengumpulkan data dari pasien paska BPAK yang bertempat tinggal di Bandung dengan melakukan kontrak waktu terlebih dahulu sehingga didapatkan sebanyak 80 responden.

Variabel bebas penelitian ini yaitu usia, jenis kelamin, tingkat pendidikan, rasa nyeri, kesehatan mental, dukungan sosial, kesejahteraan spiritual dan rehabilitasi jantung. Variabel terikat dalam penelitian ini adalah kualitas hidup pasien paska BPAK. Penelitian ini menggunakan alat ukur berupa kuesioner.
Kuesioner karakteristik responden berisi pertanyaan tentang usia, jenis kelamin dan tingkat pendidikan. Kuesioner Multidimensional Scale of Perceived Social Support (MSPSS) untuk mengukur dukungan sosial dikembangkan oleh Zimet, et al (1988). Uji validitas dan reliabilitas kuesioner MSPSS dalam penelitian Zimet, et al (2016) mendapatkan bahwa kuesioner MSPSS valid dan reliable dengan nilai Cronbach Alpha antara 0,81-0,94. Hal ini juga didukung penelitian Staniute (2013) terhadap pasien jantung yang mendapatkan nilai Cronbach Alpha 0,88 .

Kuesioner Spirituality Index of Well Being (SIWB) untuk mengukur kesejahteraan spiritual dikembangkan oleh Daaleman \& Frey pada tahun 2004. Penelitian oleh Daaleman \& Frey (2004) menjelaskan uji reliabilitas kuesioner SIWB dilakukan dengan internal consistency yang mendapatkan nilai $\alpha=0,91$ atau menunjukkan reliabilitas yang sangat kuat. Sedangkan uji validitas kuesioner SIWB dilakukan dengan confirmatory factor analysis (CFA) yang mendapatkan nilai Fit Index $\chi^{2} \quad$ (54, $\mathrm{n}=508)=508,35$ dengan $p$-value $<0,001$.

Kuesioner rehabilitasi jantung berisi satu pertanyaan dengan pilihan jawaban: tidak ikut rehabilitasi jantung, ya ikut rehabilitasi jantung dan rutin, serta ya ikut rehabilitasi jantung tetapi tidak rutin.

Kuesioner Short-Form 36 (SF 36) untuk mengukur kualitas hidup pasien paska BPAK. Uji validitas dan reliabilitas untuk kuesioner SF36 dalam penelitian Nazir (2006) dikatakan valid dan reliable dengan nilai Cronbach Alpha 0,876. Hal itu juga didukung penelitian Rochmayanti (2011) yang mendapatkan nilai Cronbach Alpha 0,841 .

Analisis data dilakukan dengan analisis univariat, bivariat dan multivariat. Analisis bivariat untuk melihat korelasi antar variabel menggunakan Point Biserial dan Rank Spearman. Dan untuk menentukan faktor memengaruhi yang paling dominan dilakukan analisis multivariat dengan teknik regresi linier.

Penelitian ini telah mendapatkan Persetujuan Etik dengan Nomor: LB.02.01/X.6.5/88/2019 oleh Komite Etik Penelitian Kesehatan RSUP Dr. Hasan Sadikin Bandung. 
HASIL

Tabel 1. Karakteristik Responden Pasien

Distribusi frekuensi karakteristik responden pasien paska BPAK didapatkan bahwa sebagian besar responden tergolong dalam usia produktif yaitu 35-64 tahun (67,5\%). Hampir seluruh responden berjenis kelamin laki-laki $(87,5 \%)$ dengan tingkat pendidikan tinggi (tamat SMA/tamat Akademik/tamat Perguruan Tinggi) $(91,3 \%)$.

Tabel 2. Gambaran Variabel Bebas dan Variabel Terikat

\begin{tabular}{lcc}
\hline \multicolumn{1}{c}{ Variabel } & Mean & \multicolumn{1}{c}{ SD } \\
\hline $\begin{array}{l}\text { Variabel Bebas } \\
\text { Rasa Nyeri } \\
\text { (Sub area SF-36) }\end{array}$ & 85,44 & 18,66 \\
$\begin{array}{l}\text { Kesehatan Mental } \\
\text { (Sub area SF-36) }\end{array}$ & 68,15 & 9,66 \\
$\begin{array}{l}\text { Dukungan Sosial } \\
\text { (Skor MSPSS) }\end{array}$ & 5,78 & 0,68 \\
$\begin{array}{l}\text { Kesejahteraan } \\
\text { Spiritual } \\
\text { (Skor SIWB) } \\
\text { Variabel Terikat } \\
\text { Kualitas Hidup } \\
\text { (Skor SF-36) }\end{array}$ & 46,53 & 6,17 \\
\hline
\end{tabular}

Tabel 2 menjelaskan bahwa kualitas hidup menunjukkan skor mean 65,59 yang berarti kualitas hidup baik. Rasa nyeri didapatkan skor mean 85,44 . Hal tersebut menunjukkan rata-rata responden berada pada kondisi yang sangat baik. Kesehatan mental didapatkan skor mean 68,15. Hal tersebut menunjukkan rata-rata responden berada pada kondisi yang baik. Dukungan sosial menunjukkan skor mean 5,78. Hal ini menjelaskan bahwa rata-rata responden mendapatkan dukungan tinggi. Kesejahteraan spiritual menunjukkan skor mean 46,53. Hal ini menjelaskan bahwa rata-rata responden memiliki kesejahteraan spiritual tinggi.

Tabel 3. Analisis Bivariat Korelasi FaktorFaktor terhadap Kualitas Hidup Pasien Paska BPAK

\begin{tabular}{lcc}
\hline \multirow{2}{*}{\multicolumn{1}{c}{ Variabel }} & \multicolumn{2}{c}{ Skor Kualitas Hidup } \\
\cline { 2 - 3 } & $\mathbf{r}$ & $\boldsymbol{p}$-value \\
\hline Usia (35-64 tahun) & $0,521^{\mathrm{a}}$ & $<0,001$ \\
$\begin{array}{l}\text { Jenis Kelamin } \\
\text { (Laki-laki) }\end{array}$ & $0,103^{\mathrm{a}}$ & 0,183 \\
$\begin{array}{l}\text { Tingkat Pendidikan } \\
\text { (Tinggi) }\end{array}$ & $0,111^{\mathrm{a}}$ & 0,163 \\
$\begin{array}{l}\text { Rasa Nyeri } \\
\text { Kesehatan Mental }\end{array}$ & $0,666^{\mathrm{b}}$ & $<0,001$ \\
$\begin{array}{l}\text { Dukungan Sosial } \\
\text { (Skor Total MSPSS) }\end{array}$ & $0,426^{\mathrm{b}}$ & $<0,001$ \\
$\begin{array}{l}\text { Kesejahteraan } \\
\text { Spiritual } \\
\text { (Skor Total SIWB) }\end{array}$ & $-0,345^{\mathrm{b}}$ & $<0,001$ \\
\hline
\end{tabular}

Hasil analisis didapatkan bahwa terdapat pengaruh usia terhadap kualitas hidup pasien paska BPAK $(\mathrm{r}=0,521, p$-value $<0,001)$. Usia 3564 tahun cenderung memiliki kualitas hidup lebih tinggi. Terdapat pengaruh rasa nyeri terhadap kualitas hidup pasien paska BPAK $(\mathrm{r}=0,666, p$ value $<0,001)$. Berkurangnya rasa nyeri akan memperbaiki kualitas hidup. Terdapat pengaruh kesehatan mental terhadap kualitas hidup pasien paska BPAK $(\mathrm{r}=0,426, p$-value $<0,001)$. Semakin baik dukungan sosial maka kualitas hidup akan semakin baik. 
Tabel 4. Analisis Regresi Linier dengan Metode Backward pada Pasien Paska BPAK

\begin{tabular}{|c|c|c|c|c|c|c|}
\hline \multirow[b]{2}{*}{ Model } & \multirow[b]{2}{*}{ Variabel } & \multicolumn{2}{|c|}{ Koefisien Regresi } & \multirow{2}{*}{$\begin{array}{c}\text { Adjusted } \\
\text { Koefisien } \\
\text { Korelasi }\end{array}$} & \multirow[b]{2}{*}{$p$-value } & \multirow[b]{2}{*}{$\mathbf{R}^{2}$} \\
\hline & & B & $\begin{array}{c}\text { Std. } \\
\text { Error }\end{array}$ & & & \\
\hline \multirow{8}{*}{$\begin{array}{c}\text { Model } \\
\text { Awal }\end{array}$} & Konstanta & 32,57 & 11,48 & & $0,006^{*}$ & 0,581 \\
\hline & Usia & 11,64 & 2,18 & 0,472 & $<0,001^{*}$ & \\
\hline & Jenis Kelamin & 0,69 & 2,90 & 0,020 & 0,814 & \\
\hline & Tingkat Pendidikan & 2,33 & 3,47 & 0,057 & 0,504 & \\
\hline & Rasa Nyeri & 0,31 & 0,06 & 0,500 & $<0,001 *$ & \\
\hline & Kesehatan Mental & 0,19 & 0,11 & 0,157 & 0,091 & \\
\hline & Skor Total MSPSS & $-2,83$ & 1,62 & $-0,166$ & 0,085 & \\
\hline & Skor Total SIWB & $-0,02$ & 0,16 & $-0,008$ & 0,925 & \\
\hline \multirow{5}{*}{$\begin{array}{l}\text { Model } \\
\text { Akhir }\end{array}$} & Konstanta & 33,69 & 9,12 & & $<0,001^{*}$ & 0,577 \\
\hline & Usia & 11,71 & 2,14 & 0,475 & $<0,001^{*}$ & \\
\hline & Rasa Nyeri & 0,31 & 0,06 & 0,497 & $<0,001 *$ & \\
\hline & Kesehatan Mental & 0,20 & 0,11 & 0,165 & 0,063 & \\
\hline & Skor Total MSPSS & $-2,78$ & 1,56 & $-0,163$ & 0,080 & \\
\hline
\end{tabular}

Analisis multivariat regresi linier dilakukan dengan metode backward. Sehingga didapatkan pada model akhir empat variabel yang tetap masuk yaitu usia, rasa nyeri, kesehatan mental, dan dukungan sosial. Urutan kekuatan hubungannya diketahui dari besarnya nilai koefisien korelasi $(r)$ yaitu rasa nyeri $(r=0,497)$ memiliki pengaruh paling besar terhadap kualitas hidup diikuti dengan usia $(\mathrm{r}=0,475)$, kemudian kesehatan mental $(\mathrm{r}=0,165)$ dan yang terakhir dukungan sosial $(\mathrm{r}=-0,163)$. Kualitas rumus yang diperoleh dari analisis multivariat pada regresi linier dapat dinilai dengan melihat diskriminasi yaitu dengan melihat nilai koefisien determinasi atau $\mathrm{R}^{2}$ dan kalibrasinya dengan melihat hasil uji ANOVA. Pada hasil penelitian ini didapatkan nilai $\mathrm{R}^{2}$ sebesar 0,577 yang menunjukkan diskriminasi yang baik. Jadi kualitas hidup dapat dijelaskan oleh keempat variabel (usia, rasa nyeri, kesehatan mental, dan dukungan sosial) sebesar $57,7 \%$.

\section{PEMBAHASAN}

Kualitas hidup pasien paska BPAK pada penelitian ini memiliki nilai rata-rata 65,59 yang menunjukkan bahwa pasien memiliki kualitas hidup yang baik. Hal ini mendukung penelitian oleh Rochmayanti (2011) yang mendapatkan nilai rata-rata 58,60 atau kualitas hidup cukup pada pasien PAK. Stillwell (2011) menyampaikan tujuan dilakukannya BPAK selain untuk mengoptimalkan fungsi jantung dan melindungi jaringan miokardium juga bertujuan memperbaiki kualitas hidup pasien.

Pada pasien paska BPAK akan mengalami perubahan baik secara fisik maupun psikologis (mental). Hal ini sesuai dengan teori Stillwell
(2011) yang menyampaikan bahwa pada pasien paska BPAK akan terjadi keterbatasan fisik dikarenakan jantung yang merupakan organ vital mengalami perubahan. Perubahan fisik meliputi perubahan fungsi dan peran fisik, adanya rasa nyeri, bahkan kesehatan secara umum. Sedangkan perubahan psikologis (mental) meliputi vitalitas, fungsi sosial, peran emosi dan kesehatan mental. Pada penelitian ini bila dilihat berdasarkan domain didapatkan domain fisik pada kualitas hidup memiliki nilai rata-rata lebih besar $(66,97)$ dibandingkan dengan nilai rata-rata domain mental $(60,86)$. Berdasarkan sub area pada domain fisik didapatkan mean tertinggi berada pada sub area rasa nyeri dengan nilai 85,44 . Berdasarkan hasil tersebut dapat dijelaskan bahwa semakin tinggi skor semakin tidak ada nyeri maka kualitas hidupnya semakin baik.

Penelitian oleh Rosidawati, et al (2016) mendapatkan bahwa secara fisik pada pasien 6 bulan pasca BPAK masih merasakan nyeri pada bekas luka operasi. Rasa nyeri pasca operasi tersebut bila dirasakan terus-menerus dapat memengaruhi kualitas hidup pasien dan dapat mengganggu aktivitas sehari-hari (Bjornnes, et al, 2017). Pada pasien pasca BPAK rasa nyeri menjadi faktor yang paling memengaruhi kualitas hidup $(r=0,497)$ namun perubahan psikologis pasien pasca operasi juga tidak dapat diabaikan.

Seperti pada penelitian Utama (2015) didapatkan bahwa operasi jantung merupakan pembedahan besar yang tidak hanya menimbulkan perubahan fisik tetapi juga stres dan cemas. Kondisi tersebut dapat memengaruhi kesejahteraan spiritual pasien sebelum dan sesudah operasi. Meskipun pada penelitian ini kesejahteraan spiritual tidak berpengaruh terhadap kualitas hidup pasien pasca BPAK ( $p$ value $>0,05)$. Hal tersebut mungkin terjadi karena 
rasa nyeri yang masih dirasakan membuat pasien merasa tidak puas dan menganggap kualitas hidupnya tidak baik.

Sejalan dengan itu penelitian Aziza (2010) didapatkan pada respon spiritual masih ada partisipan yang merasa tidak yakin dapat sembuh bahkan merasa hidupnya tidak berarti lagi. Tidak berpengaruhnya kesejahteraan spiritual terhadap kualitas hidup pasien pasca BPAK pada penelitian ini dapat pula dipengaruhi oleh persepsi pasien itu sendiri.

Sebagian besar responden berada pada rentang usia 35-64 tahun $(67,5 \%)$. Hal tersebut menunjukkan bahwa seseorang cenderung melakukan operasi BPAK ketika berada pada usia produktif. Penelitian Masoumi, et al (2017) didapatkan pula bahwa hampir setengah responden $(40,6 \%)$ berada pada rentang usia 5665 tahun. Penelitian lain oleh Bjornnes, et al (2017) juga melaporkan bahwa usia rata-rata pasien yang telah menjalani operasi BPAK adalah 65 tahun. Merujuk pada hasil penelitian tersebut pasien yang menjalani operasi BPAK banyak ditemukan pada usia produktif.

Hasil analisa korelasi Point Biserial pada variabel usia (35-64 tahun) didapatkan nilai $p$ value $<0,001$ sehingga dapat dijelaskan bahwa terdapat pengaruh usia terhadap kualitas hidup. Hasil penelitian ini mendukung penelitian Zahran, et al (2005) dan Nazir, et al (2007) yang mendapatkan bahwa usia yang lebih muda memiliki kualitas hidup yang lebih baik pada pasien paska bedah pintas koroner.

Pada hasil penelitian ini dijelaskan pula bahwa hampir seluruh responden $(87,5 \%)$ berjenis kelamin laki-laki. Hal tersebut menunjukkan bahwa laki-laki lebih banyak melakukan operasi BPAK jika dibandingkan dengan perempuan. Hasil analisa korelasi Point Biserial pada variabel jenis kelamin didapatkan nilai $p$-value $>0,05$ sehingga dapat dijelaskan bahwa tidak terdapat pengaruh jenis kelamin terhadap kualitas hidup pasien paska BPAK. Hal ini kemungkinan terjadi karena responden perempuan dalam penelitian ini sangat sedikit sehingga secara statistik perbedaan ini tidak begitu nampak.

Selanjutnya pada penelitian ini dijelaskan bahwa hampir seluruh responden $(91,3 \%)$ memiliki tingkat pendidikan tinggi (tamat SMA/tamat Akademik/tamat Perguruan Tinggi). Hasil penelitian ini sejalan dengan penelitian oleh Rochmayanti (2011) terhadap pasien dengan PAK yang mendapatkan hampir setengah responden (39\%) memiliki tingkat pendidikan SMA diikuti tingkat pendidikan Perguruan Tinggi sebanyak 34\% dan sisanya berpendidikan rendah.
Meskipun tingkat pendidikan bukan merupakan faktor resiko PAK namun tingkat pendidikan dan pengetahuan memengaruhi perilaku terhadap kesehatan. Semakin tinggi pendidikan dan pengetahuan akan mempengaruhi seseorang dalam menjalankan pola hidup sehat yang pada akhirnya berpengaruh terhadap kualitas hidup orang tersebut. Hasil analisa menunjukkan bahwa tidak terdapat pengaruh tingkat pendidikan terhadap kualitas hidup pasien paska BPAK dengan nilai $p$-value $>0,05$. Meskipun secara statistik tidak ada hubungan antara tingkat pendidikan dengan kualitas hidup namun rata-rata kualitas hidup pasien paska BPAK yang berpendidikan tinggi lebih tinggi dibandingkan dengan yang berpendidikan rendah.

Selanjutnya penelitian ini mendapatkan bahwa hampir seluruh responden $(93,75 \%)$ memiliki kesehatan mental yang tinggi. Padahal pasien sebelum dan sesudah operasi mengalami berbagai ketakutan (Urden, et al., 2010). Perasaan takut akan efek samping proses operasi dan ketakutan akan mengalami operasi yang kedua kali sering dialami oleh pasien yang menjalani BPAK.

Pada faktor dukungan sosial dalam penelitian ini didapatkan hasil bahwa hampir seluruh responden $(92,5 \%)$ memiliki dukungan sosial tinggi meskipun masih terdapat sebagian kecil responden $(7,5 \%)$ memiliki dukungan sosial sedang. Dukungan sosial yang dimaksud pada penelitian ini berasal dari keluarga, teman bahkan orang yang dianggap spesial oleh responden.

Pada penelitian ini juga masih ditemukan sebagian kecil responden (2,5\%) memiliki dukungan rendah pada subsakala penting lainnya (orang yang dianggap spesial oleh responden). Staniute (2013) menjelaskan bahwa seseorang dengan dukungan sosial rendah cenderung untuk mengalami depresi dan merokok. Sehingga dukungan sosial yang rendah dipandang sebagai faktor risiko terjadinya PAK pada individu yang sebelumnya sehat dan juga memperburuk prognosis pasien dengan PAK. Hasil analisa menunjukkan terdapat pengaruh dukungan sosial terhadap kualitas hidup pasien paska BPAK dengan nilai $p$-value $<0,001$. Pada pasien paska BPAK selain perubahan pada domain fisik juga terjadi perubahan pada domain mental. Perubahan ini merupakan proses adaptasi pasien paska BPAK untuk menerima keadaannya setelah operasi baik di rumah sakit maupun di rumah.

Hasil penelitian mendapatkan hampir seluruh responden $(96,25 \%)$ memiliki kesejahteraan spiritual tinggi. Hal ini sesuai dengan penelitian Utama (2015) yang mendapatkan bahwa seluruh pasien sebelum dan 
sesudah operasi jantung mengalami perubahan kesejahteraan spiritual.

Meskipun masih ditemukan sebagian kecil responden $(3,75 \%)$ memiliki kesejahteraan spiritual yang rendah. Kesejahteraan spiritual pada penelitian ini dinilai berdasarkan dua subskala yaitu self-efficacy dan life-scheme.

Seluruh responden $(100 \%)$ pada penelitian ini memiliki Self-Efficacy yang tinggi. Hal ini menunjukkan bahwa responden berkeyakinan bahwa dirinya mampu memahami serta mengatasi masalah fisik dan mental yang terjadi paska BPAK dalam upaya mencapai kualitas hidup yang optimal.

Pada penelitian ini didapatkan bahwa seluruh responden $(100 \%)$ mengikuti program rehabilitasi jantung secara rutin yaitu 2 kali seminggu dan sesusai jadwal. Program rehabilitasi jantung bertujuan memulihkan kondisi fisik, mental serta sosial seoptimal mungkin. Hal ini mendukung penelitian oleh Masoumi, et al (2017) yaitu terjadi peningkatan kualitas hidup pada pasien yang menjalani BPAK setelah intervensi rehabilitasi jantung.

Kualitas hidup pasien pasca BPAK pada penelitian ini dipengaruhi oleh faktor usia, faktor rasa nyeri, faktor kesehatan, dan faktor dukungan sosial. Diantara keempat faktor tersebut didapatkan faktor rasa nyeri merupakan faktor yang paling memengaruhi kualitas hidup pasien paska BPAK. Rasa nyeri ini bersifat akut dan terjadi karena adanya kerusakan jaringan akibat proses pembedahan.

Respon seseorang terhadap rasa nyeri dibentuk oleh berbagai faktor salah satunya yaitu usia. Smeltzer \& Bare (2010) menjelaskan bahwa usia mempunyai peranan penting dalam mempersepsikan dan mengekspresikan rasa nyeri. Pada pasien usia produktif (35-64 tahun) rasa nyeri sering dianggap hal yang wajar sehingga mereka tidak melaporkan rasa nyeri. Hal ini mendukung Potter \& Perry (2010) yang menjelaskan bahwa pada pasien usia 35-64 tahun rasa nyeri dianggap sebagai hal yang dapat diterima sehingga keluhan sering diabaikan.

\section{SIMPULAN}

Faktor-faktor yang memengaruhi kualitas hidup pasien paska BPAK di RSUP Dr. Hasan Sadikin Bandung yaitu usia, rasa nyeri, kesehatan mental dan dukungan sosial. Adapun faktor yang paling memengaruhi kualitas hidup pasien paska BPAK di RSUP Dr. Hasan Sadikin Bandung adalah rasa nyeri. Sehingga dalam memberikan asuhan keperawatan pada pasien paska BPAK perlu mempertimbangkan rasa nyeri, usia, kesehatan mental dan dukungan sosial. Khususnya penerapan manajemen nyeri dan manajemen stres pada discharge planning.

\section{DAFTAR PUSTAKA}

Alexander, J. H., \& Smith, P. K. (2016). Coronary-artery bypass grafting. New England Journal of Medicine, 374(20), 1954-1964.

Aziza, W. (2010). Pengalaman Klien tentang Perawatan Post CABG terhadap Kualitas Hidup dalam Konteks Asuhan Keperawatan: Study Fenomenologi di Unit Pelayanan Jantung Terpadu RSUPN Dr. Cipto Mangunkusumo Jakarta. [Tesis]. Depok: Fakultas Ilmu Keperawatan, Universitas Indonesia.

Bak, E., \& Marcisz, C. (2014). Quality of life in elderly patients following coronary artery bypass grafting. Patient preference and adherence, 8, 289.

Bjørnnes, A. K., Parry, M., Falk, R., WattWatson, J., Lie, I., \& Leegaard, M. (2017). Impact of marital status and comorbid disorders on health-related quality of life after cardiac surgery. Quality of Life Research, 26(9), 2421-2434.
Cassar, S., \& Baldacchino, D. R. (2012). Quality of life after percutaneous coronary intervention: part 1. British Journal of Nursing, 21(16), 965-971.

Department of Cardiothoracic Surgery. (2017). Coronary Artery Bypass Grafting (CABG). National Heart Centre Singapore. https://www.singhealth.com.sg/patientcare/conditions-treatments/coronaryartery-bypass-grafting.

Direk, F., Celik, S. S., \& Lefkoşa, K. K. T. (2012). Postoperative problems experienced by patients undergoing coronary artery bypass graft surgery and their self-care ability after discharge. Turkish J Thorac Cardiovasc Surg, 20(3), 530-535.

Hlatky, M. A., Boothroyd, D. B., Bravata, D. M., Boersma, E., Booth, J., Brooks, M. M., ... \& Pocock, S. J. (2009). Coronary artery bypass surgery compared with percutaneous coronary interventions for 
multivessel disease: a collaborative analysis of individual patient data from ten randomised trials. The Lancet, 373(9670), 1190-1197.

Khoueiry, G., Flory, M., Rafeh, N. A., Zgheib, M. H., Goldman, M., Abdallah, T., Wettimuny, S., Telesford, B., Costantino, T. \& McGinn, J. T. (2011). Depression, Disability and Quality of Life After OffPump Coronary Artery Bypass Grafting: A Prospective 9 Month Follow-Up Study. Heart \& Lung, 40(3), 217-225. doi: 10.1016/j.hrtlng.2010.03.001.

Mampuya, W. M. (2012). Cardiac rehabilitation past, present and future: an overview. Cardiovascular diagnosis and therapy, 2(1), 38.

Masoumi, S. Z., Kazemi, F., Khani, S., Seifpanahi-Shabani, H., Garousian, M., Ghabeshi, M., ... \& Roshanaei, G. (2017). Evaluating the effect of cardiac rehabilitation care plan on quality of life of patients undergoing coronary artery bypass graft surgery. International Journal of Cardiovascular Practice, 2(2), 44-50.

Middel, B., Baz, N. E., Pedersen, S. S., Van Dijk, J. P., Wynia, K. \& Reijneveld, S. A. (2014). Decline in Health-Related Quality of Life 6 Months After Coronary Artery Bypass Graft Surgery The Influence of Anxiety, Depression and Personality Traits. Journal of Cardiovascular Nursing. 29 (6), 544-554.

Mouch, C. A., \& Sonnega, A. J. (2012). Spirituality and recovery from cardiac surgery: A review. Journal of religion and health, 51(4), 1042-1060.

National Heart, Lung and Blood Institute (NHLBI). (2014). Coronary Heart Disease. http://www.nhlbi.nih.gov/helthtopics/coronary-heart-disease

National Health Service (NHS). (2015). Coronary Artery Bypass Graft. https://www.nhs.uk/conditions/coronaryartery-bypass-graft-cabg/

Nazir, K. A., Kalim, H. \& Radi, B. (2007). Penilaian Kualitas Hidup Pasien Pasca Bedah Pintas Koroner yang Menjalani Rehabilitasi Fase III. Jurnal Kardiologi Indonesia. (28)3.

Nuraeni, A., Mirwanti, R., Anna, A., Prawesti, A. \& Emaliyawati, E. (2016). Faktor yang Memengaruhi Kualitas Hidup Pasien dengan Penyakit Jantung Koroner. Jurnal Keperawatan Padjajaran. 4(2). 107-116.

Potter, P., \& Perry, A. (2010). Fundamental of Nursing. Jakarta: EGC.
Pusat Data dan Informasi Kemenkes RI. (2012). Gambaran Penyakit Tidak Menular di Rumah Sakit di Indonesia Tahun 2009 dan 2010. Buletin Jendela Data dan Informasi Kesehatan, 2(2), 1-14.

Radi, B., Joesoef, A. H. \& Kusmana, D. (2009). Rehabilitasi Kardiovaskular di Indonesia. Jurnal Kardiologi Indonesia. 30(2).

Rochmayanti. (2011). Analisis Faktor-faktor yang Mempengaruhi Kualitas Hidup Pasien Penyakit Jantung Koroner di Rumah Sakit PELNI Jakarta. [Tesis]. Depok: Universitas Indonesia.

Rosidawati, I., Ibrahim, K., Nuraeni, A. (2016). Kualitas Hidup Pasien Pasca Bedah Pintas Arteri Koroner (BPAK) di RSUP Dr. Hasan Sadikin Bandung. Jurnal Keperawatan Padjajaran. 4(2).

Smeltzer, S. C. \& Bare B. G. (2008). Text Book of Medical Surgical Nursing. Lippincott. Philadelphia.

Staniute, M., Brozaitiene, J., \& Bunevicius, R. (2013). Effects of social support and stressful life events on health-related quality of life in coronary artery disease patients. Journal of Cardiovascular Nursing, 28(1), 83-89.

Stillwell, S. (2011). Pedoman Keperawatan Kritis. Jakarta: EGC.

Taghipour, H. R., Naseri, M. H., Safiarian, R., Dadjoo, Y., Pishgoo, B., Mohebbi, H. A., Besheli, L. D., M Malekzadeh, M. \& Kabir, A. (2011). Quality of Life One Year after Coronary Artery Bypass Graft Surgery. Iranian Red Crescent Medical Journal, 13(3), 171-7.

Urden, L. D., Stacy, K. M., Lough, M. E. (2010). Critical care nursing: Diagnosis and management. Canada: Mosby Elsevier.

Utama, T. A. (2015). Perbedaan Kesejahteraan Spiritual Pasien Sebelum Dan Sesudah Operasi Jantung Di RSUP Dr Hasan Sadikin Bandung. [Tesis]. Bandung: Universitas Padjajaran.

Ventegodt, S., Merrick, J., \& Andersen, N. J. (2003). Quality of life theory I. The IQOL theory: an integrative theory of the global quality of life concept. TheScientificWorldJOURNAL, 3, 1030-1040.

Zahran, H. S., Kobau, R., Moriarty, D. G., Zack, M. M., Holt, J. \& Donehoo, R. (2005). Health-Related Quality of Life Surveillance United States,1993-2002. Morbidity and Mortality Weekly Report: Surveillance Summaries. Vol. 54 No. 4, 1- 
35. Centers for Disease Control and Prevention (CDC).

Zimet, G. D., Dahlem, N. W., Zimet, S. G., \& Farley, G. K. (1988). The multidimensional scale of perceived social support. Journal of personality assessment, 52(1), 30-41.
Zimet, G. (2016). Multidimensional Scale of Perceived Social Support (MSPSS)-Scale Items and Scoring Information. https://www.researchgate.net/publication/3 11534896. 